\title{
UPAYA PENINGKATAN MINAT BELAJAR BACA TULIS AI-QUR'AN
}

\author{
Muh. Aidil Sudarmono \\ muhaidil.sudarmono@umi.ac.id \\ Abdul Wahab \\ abdulwahab79@umi.ac.id \\ Muh. Azhar \\ muhazhar.burhanuddin@umi.ac.id
}

\begin{abstract}
Abstrak
Jurnal ini membahas mengenai peningkatan minat belajar baca tulis alQur'an. Dalam rangka peningkatan minat belajar baca tulis al-Qur'an pada peserta didik, diperlukan upaya-upaya khususnya terutama para guru Pendidikan Agama Islam. Sebab peserta didik khususnya pada tingkat Sekolah Dasar masih sangat membutuhkan bimbingan dalam hal baca tulis al-Qur'an. Pembahasan tentang peningkatan minat belajar baca tulis al-Qur'an dan apa yang menjadi faktor penghambat dan pendukung peningkatan minat belajar baca tulis al-Qur'an menjadi sangat penting untuk dikaji. Bentuk upaya peningkatan minat belajar baca tulis AlQur'an yaitu menasehatimelalui perkataan, mendoakan peserta didik, pujian sebagai motivasi, kasih sayang yang tulus, mendidik dengan keteladanan, tidak berlebihan dalam menasihati, pembiasaan secara bertahap, serta menghukum dan memberi penghargaan. Faktor penghambat peningkatan minat belajar baca tulis Al-Qur'an yaitu faktor keluarga meliputi cara orang tua mendidik anak, relasi antar anggota keluarga, dan suasana rumah tangga, faktor lingkungan masyarakat yang tidak berpendidikan, serta faktor lingkungan sekolah terutama pergaulan teman sebaya. Sedangkan faktor yang mendukung dabagi menjadi bagian yaitu faktor jasmani meliputi kesehatan dan cacat tubuh, faktor psikologis meliputi intelegensi, perhatian, minat, dan bakat, serta faktor kelelahan meliputi kelelahan jasmani dan rohani.
\end{abstract}

Kata kunci: minat belajar, 


\section{PENDAHULUAN}

Pendidikan merupakan suatu hal yang sangat penting bagi kehidupan manusia, baik dari segi kehidupan diri sendiri, keluarga, masyarakat, maupun bernegara. Dalam UndangUndang RI nomor 20 Tahun 2003 tentang Sistem Pendidikan Nasional bab I pasal (1) dijelaskan bahwa:

Pendidikan adalah usaha sadar dan terencana untuk mewujudkan suasana belajar dan proses pembelajaran agar peserta didik secara aktif mengembangkan potensi dirinya untuk memiliki kekuatan spiritual keagamaan, pengendalian diri, kepribadian, kecerdasan, akhlak mulia, serta keterampilan yang diperlukan dirin ya, masyarakat, bangsa dan negara. ${ }^{1}$

Sedangkan tujuan pendidikan nasional Menurut Undang-Undang RI nomor 20 Tahun 2003 tentang Sistem Pendidikan Nasional bab II pasal (3) bahwa:

Pendidikan nasional berfungsi mengembangkan kemampuan dan membentuk watak serta peradaban bangsa yang bermartabat dalam mencerdaskan kehidupan bangsa, bertujuan untuk berkembangnya potensi peserta didik agar menjadi manusia yang beriman dan bertaqwa kepada Tuhan Yang Maha Esa, berakhlak mulia, sehat, berilmu, cakap, kreatif, mandiri dan menjadi warga negara yang demokratis serta bertanggung jawab. ${ }^{2}$

Salah satu yang menjadi aspek pendukung untuk mencapai tujuan pendidikan agama adalah kemampuan peserta didik dalam membaca al-Qur'an. Karena al-Qur'an merupakan kitab suci bagi umat Islam yang menjadi pokok dari ajaran agama Islam.

Al-Qur'an secara istilah adalah kalam Allah Swt yang merupakan mu'jizat yang diturunkan (diwahyukan) kepada Nabi Muhammad dan membacanyaadalah ibadah. ${ }^{8}$ Allah Swt berfirman dalam Al-Qur'an QS. al-Baqarah/2: 2:

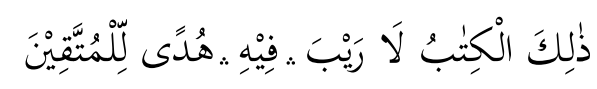

Terjemahnya:

Kitab (Al-Qur'an) ini tidak ada keraguan padanya; petunjuk bagi mereka yang bertakwa. ${ }^{3}$

Ayat di atas menjelaskan bahwa salah satu fungsi Al-Qur'an ialah menjadi petunjuk khususnya bagi orang yang bertakwa.

Quraish Syihab menjelaskan fungsi yang diperoleh dalam membaca Al-Qur'an

\footnotetext{
${ }^{1}$ Unda ng-undang Republik Indonesia No. 20 Ta; hun 2003, Tentang Sistem Pendidikan Nasional 2003. (Jakarta: Cemerlang, 2003), h. 3.

${ }^{2}$ Unda ng-undang Republik Indonesia No.20 tahun 2003.op.cit., h. 7. 2009),h.2.

${ }^{3}$ Departemen Agama Republik Indonesia, Al-Qur'an dan terjemahnya (Semarang: Toha Putra,
} 
yaitu memberi petunjuk bagi kesejahteraan umat muslim di samping berbagai fungsi lainnya. Namun yang perlu kita cermati, fungsi-fungsi al-Qur'an tersebut tidak akan ada artinya tanpa membaca dan memahaminya. ${ }^{4}$ Untuk dapat memahami petunjuk tersebut, umat Islam harus memahami tafsir dari ayat al- Qur'an. Sedangkan untuk menafsirkan sebuah ayat, tentu saja langkah awal yang ditempuh adalah membaca ayatnya.

Begitu pentingnya peran al-Qur'an dalam kehidupan, maka menjadi kewajiban bagi setiap umat muslim untuk memiliki kemampuan dasar membaca Al-Qur'an. Keputusan bersama Menteri Dalam Negeri dan Menteri Agama RI nomor 128 tahun 1982/44 A 82 menyatakan bahwa perlunya usaha peningkatan kemampuan baca tulis al-Qur'an bagi umat muslim dalam rangka peningkatan penghayatan dan pengalaman al-Qur'an dalam kehidupan sehari - hari. Keputusan bersama ini ditegaskan pula oleh Instruksi menteri Agama RI nomor 3 tahun 1990 tentang pelaksanaan upaya peningkatan kemampuan baca tulis al-Qur'an. ${ }^{5}$ Bedasarkan keputusan di atas, dapat dipahami bahwa betapa pentingnya umat muslim memningkatkan kemampuan membaca dan memahami Al-Qur'an.

\section{Minat Belajar}

Minat berarti dorongan dari dalam hati, keinginan yang kuat, gairah, dan kecenderungan hati yang sangat tinggi terhadap sesuatu. Minat besar pengaruhnya terhadap belajar, karena bila bahan pelajaran yang dipelajari tidak sesuai dengan minat peserta didik, maka proses pembelajaran tidak akan terlaksana secara efektif sebab tidak ada daya tarik. Sedangkan minat belajar adalah keinginan kuat yang disadari atau disengaja yang juga melibatkan aktivitas visual, berpikir, psikolinguistik, dan metakognitif dalam menerjemahkan simbol tulisan (huruf) ke dalam bentuk kata- kata lisan.

Minat adalah suatu rasa lebih suka dan rasa keterkaitan suatu hal atau aktivitas tanpa ada yang menyuruh. Minat pada dasarnya adalah penerimaan akan suatu hubungan antara diri sendiri dengan sesuatu di luar diri. Semakin kuat dan dekat hubungan tersebut semakin besar. ${ }^{6}$ Sedangkan belajar merupakan suatu proses di mana suatu organisme berubah perilakunya sebagai akibat dari pengalaman. Belajar merupakan suatu proses yang berlangsung dalam jangka waktu yang lama melalui latihan maupun pengalaman yang membawa kepada perubahan diri dan perubahan cara mereaksi terhadap perangsang tertentu.

Selain itu, belajar adalah upaya untuk memperoleh kebiasaan-kebiasaan, pengetahuan, dan sikap. ${ }^{7}$ Jadi, Belajar merupakan suatu proses yang kompleks yang terjadi pada diri setiap individu sepanjang hidupnya. Proses belajar itu terjadi karena interaksi antara seseorang dengan lingkungannya. Oleh karena itu, belajar dapat terjadi kapanpun dan di manapun. Apabila proses belajar itu diselenggarakan secara formal di tempat-tempat pendidikan, tidak lain hal itu bertujuan untuk mengarahkan perubahan pada diri setiap siswa secara terencana baik dari segi pengetahuan, keterampilan, maupun sikap.

\section{Baca Tulis Al-Qur'an}

\footnotetext{
${ }^{4}$ M.Qura ish Syihab, Lentera Hati (Bandung: Mizan, 1996), h. 28.

${ }^{516}$ Ahmad Syarifuddin, Mendidik Anak Menulis, Membaca, Dan Mencintai AL-qur'an. (Jakarta: Gema Insani, 2004), h. 41.

${ }^{6}$ Sya iful Bahri Dja marah, Psikologi Belajar (Jakarta: Rineka Cipta, 2002), h. 132.

${ }^{7}$ Sya iful Sa gala, Konsep dan Makna Pembelajaran (Cet.8; Bandung: Alfabeta, 2010), h. 13.
} 
Baca tulis al-Qur'an adalah kegiatan pembelajaran yang tidak ditekankan pada upaya memahami informasi, tetapi ada pada tahap melafalkan (melisankan) lambanglambang. Adapun tujuan dari baca tulis al-Qur'an adalah pembelajaran membaca permulaan agar siswa dapat membaca kata-kata dengan kalimat sederhana dengan lancar dan tertib.

\section{Upaya Peningkatan Minat Belajar Baca Tulis Al-Qur'an}

Dalam peningkatan minat belajar baca tulis al-Qur'an disekolah yang paling berperan adalah guru pendidikan Agama Islam dan mata pelajaran yang terkait dengan pendidikan agama. Tugas guru adalah berusaha secara sadar untuk membimbing, mengajar dan melatih siswa yang bertujuan untuk:

a. Meningkatkan keimanan dan ketakwaan kepada Allah swt yang telah ditanamkan dalam lingkungan keluarga.

b. Menyalurkan bakat dan minatnya dalam mendalami bidang agama serta mengembangkannya secara optimal, sehingga dapat dimanfaatkan untuk dirinya sendiri dan dapat pula bermanfaat bagi orang lain .

c. Memperbaiki kesalahan-kesalahan, kekurangan-kekurangan dan kelemahankelemahannya dalam keyakinan, pemahaman dan pengamalan ajaran Islam dalam kehidupan sehari-hari.

d. Menangkal dan mencegah pengaruh negatif dari kepercayaan, paham atau budaya lain yang membahayakan dan menghambat perkembangan keyakinan siswa.

e. Menyesuaikan diri dengan lingkungannya, baik lingkungan fisik maupun lingkungan sosial yang sesuai dengan ajaran Islam.

f. Menjadikan ajaran Islam sebagai pedoman hidup untuk mencapai kebahagiaan hidup di dunia dan akhirat.

g. Mampu memahami, mengilmui pengetahuan agama Islam secara menyeluruh sesuai dengan daya serap siswa dan keterbatasan waktu yang tersedia. ${ }^{8}$

Metode pendidikan Rasulullah saw dapat diterapkan dalam pendidikan di dalam rumah tangga ataupun di sekolah. Secara umum, metode ini saling menunjang antara satu sama lain. Adapun metode yang digunakan Nabi Saw dalam mendidik yaitu menasehati melalui perkataan, mendoakan peserta didik, pujian sebagai motivasi, kasih sayang yang tulus, mendidik dengan keteladanan, tidak berlebihan dalam menasihati, pembias aan secara bertahap, serta menghukum dan memberi penghargaan. ${ }^{9}$ Untuk lebih jelasnya dapat di lihat di bawah ini.

a. Menasihati melalui perkataan.

Dalam kamus besar bahasa Indonesia menyebutkan bahwa makna nasehat adalah ajaran yang baik. Itu berarti menasehati adalah mengajarkan kebaikan. Setiap guru pastilah

${ }^{8}$ Zulfa Rosyidah, "Upaya Guru Pendidikan Agama Islam Dalam Meningkatkan Kemampuan baca tulis Al-Qur'an pada anak didik di SDN Sidorejo 01 Doko Blitar" (Skripsi Sarjana, Fakultas Tarbiyah UIN Malang, 2008), h. 10.

${ }^{9}$ Wendi Zarman, Ternyata Mendidik Anak Cara Rasulullah Itu Mudah \& Lebih Efektif (Cet, IV; Bandung: Ruang Kata Imprint Kawan Pustaka, 2012), h. 158. 
pernah melakukan cara ini kepada peserta didiknya. Jika kita perhatikan, sebagian besar kandungan ayat-ayat al-Qur'an merupakan nasehat langsung kepada pembacanya.

b. Mendoakan peserta didik.

Rasulullah saw adalah orang yang sangat suka berdoa. Betapapun kerasnya kita mengupayakan keberhasilan peserta didik, maka pada akhirnya Allah swt juga yang menentukan. Untuk itu sebagai guru kita harus senantiasa mendoakan anak didik kita dan melakukan pengajaran yang baik dengan metode yang menarik yang dapat meningkatkan minat belajar peserta didik. Jangan sekali-kali mendoakan keburukan bagi peserta didik, oleh karena itu kita harus berhati-hati pada saat memarahi peserta didik agar tidak keluar kata-kata yang akan mendoakan sesuatu yang buruk untuk anak didik kita.

c. Pujian Sebagai Motivasi.

Terkadang kita sulit menemukan cara untuk memotivasi anak. Berulang kali kita menasehati, baik dengan cara halus maupun tegas, tetapi tetap saja tidak ada perubahan. Metode memberikan pujian ini sangat baik untuk diterapkan dalam proses pendidikan. Untuk membangkitkan motivasi anak, sebaiknya para guru membagi-bagikan piala sederhana kepada seluruh siswa tampa terkecuali. Pada setiap piala dituliskan kelebihan dari masing-masing siswa.

Dalam memotivasi siswa guru perlu kreatif dalam mempraktekkan metode memuji ini ketika menasehatinya. Satu hal yang tidak boleh dilupakan adalah untuk bisa memberi efek perubahan yang kuat kepada siswa, anda harus menjadi pribadi yang mengagumkan bagi siswa terlebih dahulu. Jika selama ini anda sering marah sebaiknya anda mengurangi kebiasaan tersebut.

\section{d. Kasih Sayang Yang Tulus.}

Rasulullah saw meminta agar setiap guru untuk menunjukkan ekspresi kasih sayang mereka kepada siswa, seperti memperhatikan peserta didik. Hal ini ditunjukkan langsung oleh Rasulullah kepada anak cucunya. Disini dapat kita lihat bahwa sentuhan kasih sayang itu demikian penting.

\section{e. Mendidik Dengan Keteladanan.}

Keteladanan adalah ruh dari pendidikan. Dengan keteladanan, pendidikan menjadi bermakna dan tampa keteladanan, pendidikan hanyalah suatu indoktrinasi dan kemunafikan. Keteladanan merupakan kekuatan kunci dari pendidikan Rasulullah saw tidak diragukan lagi, keteladanan merupakan metode pendidikan yang efektif. Oleh karena itu, sebagai guru yang akan menerapkan metode keteladanan terlebih dahulu memperbaiki sifatnya untuk menjadi teladan dari siswanya. Selain itu, guru juga harus mencermati siapa yang diidolakan oleh siswanya.

\section{f. Tidak Berlebihan dalam Menasehati.}

Sesuatu akan indah jika dilakukan sesuai dengan kadarnya. Demikian juga dalam menasehati siswa. Bentuk tidak berlebihan adalah tidak terlalu sering menasehati, hal inilah yang dicontohkan Rasulullah saw. Bentuk lain dari tidak berlebihan dalam menasehati 
siswa adalah dengan menasehati siswa secara singkat atau tidak berpanjang-panjang.

g. Pembiasaan Secara Bertahap.

Metode ini sebenarnya telah dicontohkan dalam al-Qur'an yang menetapkan hukum-hukum syariatyang ditegakkan secara bertahap. Metode pembiasaan ini meru pakan metode yang baik dalam membentuk karakter, salah satu keunggulan dari metode ini adalah biasanya dampaknya lebih panjang. Numun tidak dipungkiri juga bahwa proses pembentukan pembiasaan juga butuh waktu yang panjang untuk mendapatkan hasilnya.

h. Menghukum Dan Memberi Penghargaan.

Setiap siswa pada dasarnya memiliki pembawaan yang berbeda-beda. Perbedaan ini menyebabkan perbedaan karakter pada siswa, sehingga menyebabkan perbedaan tanggapan yang beda pula pada saat menjalani proses pendidikan. Adanya perbedaan karakter ini membutuhkan pendekatan yang berbeda pula. Pendekatan yang berbeda ini diantaranya dapat dilakukan melalui kombinasi antara memberi hukuman dan memberi penghargaan. Meski demikian, pendidikan dalam Islam adalah pendidikan yang menekankan kelembutan dan keramahan.

\section{Metode Pengajaran Baca Tulis Al-Qur'an}

Prinsip pengajaran al-Qur'an pada dasarnya bisa dilakukan dengan bermacammacam metode. Diantara metode-metode itu ialah sebagai berikut.

a. Guru membaca terlebih dahulu, kemudian disusul anak atau murid. Dengan metode ini, guru dapat menerapkan cara membaca huruf dengan benar melalui lidahnya. Sedangkan anak akan dapat melihat dan menyaksikan langsung praktik keluarnya huruf dari lidah guru untuk ditirukannya, yang disebut dengan Musyafahah 'adu lidah'. metode ini diterapkan oleh Nabi Muhammad saw kepada kalangan sahabat.

b. Murid membaca di depan guru, sedangkan guru menyimaknya. Metode ini dikenal dengan metode sorogan atau 'ardul Qiro'ah' atau setoran bacaan. Metode ini dipraktikkan oleh Rasulullah saw bersama malaikat Jibril pada tes bacaan al-Qur'an di bulan Ramadhan.

c. Guru mengulang-ulang bacaan, sedang anak atau murid menirukannya kata per kata dan kalimat per kalimat juga secara berulang-ulang hingga terampil dan benar. Dari ketiga metode ini, metode yang banyak diterapkan di kalangan anak-anak pada masa kini ialah metode kedua, karena dalam metode ini terdapat sisi positif yaitu aktifnya murid CBSA (Cara Belajar Siswa Aktif). Untuk tahap awal, proses pengenalan kepada anak-anak pemula, metode yang tepat ialah metode pertama sehingga anak atau murid telah mampu mengekspresikan bacaan huruf hurufhijaiyah secara tepat dan benar. Sedangkan metode ketiga cocok untuk mengajar anak yang menghafal.

\section{Proses Belajar Baca Tulis Al-Qur'an}

Proses belajar berarti suatu tahapan dalam bentuk pembelajaran membaca alQur'an. Setiap proses belajar diikuti oleh sub proses belajar serta serangkaian fase-fase. Rangkaian fase-fase tersebut dapat ditemukan dalam setiap jalur pendidikan. Dalam buku kitabah bahwa metode praktis membaca dan menulis al- Qur'an yaitu: 
a. Klasikal yaitu guru mengajarkan setiap materi pelajaran kepada siswa dan memberikan contoh yang benar cara pengucapan dan penulisannya.

b. Menyimak yaitu siswa membaca contoh-contoh kalimat yang telah diberikan, sementara guru menyimak dan memberikan koreksi terhadap cara pengucapan siswa.

c. Mandiri yaitu siswa belajar secara mandiri materi-materi yang telah dipelajarinya. Dalam proses belajar baca tulis al-Qur'an diatas agar benar- benar ditekankan ketepatan dalam hal makhroj tiap-tiap huruf, panjang pendeknya bacaan (mad) dan ghunnah. Setelah siswa dapat membaca dengan benar maka siswa diminta untuk menyalin contohcontoh kalimat yang ada, sebab dengan menulis siswa akan lebih mudah hafal dan menguasai materi tersebut. Materi latihan selain sebagai bahan evaluasi membaca juga dapat digunakan sebagai materi evaluasi menulis, dengan cara guru/penguji membaca kata/kalimat siswa menuliskan kata/kalimat tersebut.

\section{Faktor-faktor yang Mendukung dan Menghambat, serta Upaya Untuk Mengatasi kendala-kendala dalam Peningkatan Minat Belajar Baca Tulis al-Qur'an.}

Adapun faktor-faktor yang mempengaruhi pembelajaran al-Qur'an adalah:

\section{Faktor Yang Mendukung}

Faktor ini masih dibagi menjadi tiga bagian yaitu :

a. Faktor Jasmaniah, yang termasuk faktor jasmaniah adalah : pertama kesehatan, dimana kesehatan seseorang akan berpengaruh terhadap belajarnya. Dan kedua cacat tubuh yaitu sesuatu yang menyebabkan kurang sempurna mengenai tubuh. Keadaan cacat tubuh ini juga mempengaruhi belajar.

b. Faktor Psikologis, ini dibagi menjadi empat bagian yaitu: pertama, Intelegensi yaitu kecakapan yang terdiri dari tiga jenis yaitu kecakapan untuk menghadapi dan menyesuaikan kedalam situasi yang baru dengan cepat dan efektif, mengetahui konsep-konsep yang abstrak secara efektif, mengetahui relasi dan mempelajarinya dengan cepat. Kedua, Perhatian yaitu untuk dapat menjamin hasil belajar yang baik maka siswa harus mempunyai perhatian terhadap bahan yang dipelajarinya, jika bahan pelajaran tidak menjadi perhatian siswa maka timbullah kebosanan sehingga ia tidak lagi suka belajar. Ketiga, minat yaitu kecenderungan yang tetap untuk memperhatikan dan mengenang beberapa kegiatan. Minat besar pengaruhnya terhadap belajar, karena bila bahan pelajaran yang dipelajari tidak sesuai dengan minat siswa, siswa tidak akan belajar dengan sebaikbaiknya karena tidak ada daya tarik. Dan keempat, bakat adalah kemampuan untuk belajar, dimana kemampuan itu baru akan terealisasi menjadi kecakapan yang nyata sesudah belajar atau berlatih.

c. Faktor kelelahan, yang meliputi dua macam yaitu kelelahan jasmani dan kelelahan rohani (bersifat psikis). Adapun kelelahan jasmani terlihat dengan lemah lunglainya tubuh dan timbul kecenderungan untuk membaringkan tubuh. Ini terjadi karena terjadi kekacauan substansi sisa pembakaran dalam tubuh sehingga darah kurang lancar pada bagian tertentu. Sedangkan kelelahan rohani dapat dilihat dengan adanya kelesuan dan kebosanan, sehingga minat dan dorongan untuk menghasilkan sesuatu hilang.

2. Faktor Yang Menghambat 
Faktor menghambat ada tiga yaitu:

a. Faktor keluarga, disini berupa pertama cara orang tua mendidik misalnya acuh tak acuh terhadap belajar anaknya, tidak memperhatikan sama sekali akan kebutuhan anaknya dalam belajar, tidak mau tahu bagaimana kemajuan belajar anaknya. Kedua Relasi antar anggota keluarga yang terpenting adalah relasi orang tua dan anaknya. Adapun wujud dari relasi itu misalnya apakah hubungan itu penuh dengan kasih sayang dan pengertian atau diliputi oleh kebencian dan sikap yang terlalu keras dan lain-lain. Dan ketiga suasana rumah tangga dimaksudkan sebagai situasi yang sering terjadi dalam keluarga dimana berada dan belajar, suasana rumah juga merupakan faktor yang penting yang tidak termasuk faktor yang disengaja.

b. Faktor lingkungan masyarakat, suatu lingkungan masyarakat yang tidak terpelajar juga dapat mempengaruhi belajar siswa, selain itu kegiatan siswa dalam hidup bermasyarakat juga ikut turut menentukan terhadap keberhasilan anak didik tersebut.

c. Faktor dari lingkungan sekolah, maksud dari faktor lingkungan sekolah di sini ialah faktor pergaulan dari peserta didik dengan teman-temannya di sekolah. Selain itu, kurikulum sekolah juga kadang menghambat karena kurang mendukung dalam proses peningkatan minat belajar baca tulis al-Qur'an. Permasalahan seperti ini umumnya muncul pada sekolah dasar (SD) yang siswanya dari semua jenis agama, tidak sama halnya dengan madrasah ibtidayah (MI).

\section{Upaya Untuk Mengatasi Kendala-Kendala Dalam Peningkatan Minat Baca Tulis al- Qur'an.}

Selama ini upaya yang dilakukan guru PAI adalah memfokuskan kepada siswa yang kurang mampu baca tulis al-Qur'an, dengan jalan pemberian metode iqra. Bermacammacam metode tentang pengajaran al-Qur'an seperti metode musyafahah yaitu metode pengajaran dengan cara guru memberikan contoh pengucapan langsungkepada siswa. yang kedua sorogan metode ini dengan jalan siswa secara aktif langsung praktek membaca dihadapan guru. Dan masih banyak lagi metode pengajaran al-Qur'an yang dapat dipilih oleh guru-guru PAI dalam mengajarkan baca tulis al-Qur'an.

Selain pemilihan metode yang baik, upaya yang dilakukan guru dalam peningkatan minat baca tulis al-Qur'an adalah dengan melakukan penambahan sarana dan prasarana dalam pembelajaran al-Qur'an. Misalnya, buku-buku metode baca tulis al-Qur'an, menambah jumlah al-Qur'an dan media pembelajaran audio visual (TV, CD, Tape recorder). Agar anak-anak tidak bosan dalam mempelajari baca tulis al-Qur'an.

Terkait dengan pendidikan al-Qur'an anak-anak, tidak terlepas dari motivasi dari orang tua. Karena masa kanak-kanak merupakan masa yang labil, naik turun, tidak mantap, dan mudah berubah-ubah. Sementara, masa ini diyakini sebagai masa yang sangat penting bagi warna atau watak hidup seseorang kelak. Dari itu, agar anak dapat tekun, rajin dan disiplin dalam belajar baca tulis al- Qur'an, maka orang tua harus melakukan pembiasaan belajar al-Qur'an pada anak. Motivasi ini dalam rangka menggali dan mengaktualkan potensi positif yang ada dalam diri anak, sebelum potensi negatif mempengaruhi dan menacap pada diri anak. 
Peran motivasi dari orang tua ini bertambah penting mengingat banyak kendala yang menjadikan anak tidak dapat tekun, rajin, dan disiplin dalam belajar al-Qur'an, seperti kendala lingkungan, televisi, teman, dan kendala berupabudaya sifat malu dan merasa bisa. Bentuk motivasi pada anak, orang tua dapat memberikan hadiah atau pyujian yang sewajarnya jika anak tekun, rajin, dan disiplin. Pemberian motivasi seperti ini akan berpengaruh cukup besar dalam mendorong anak tekun, rajin, dan disiplin dalam mempelajari al-Qur'an.

Adapun upaya yang dilakukan untuk mengatasi kurangnya motivasi orang tua terhadap putra-putrinya adalah dengan jalan pemberian semacam pengarahan tentang pentingnya pembelajaran al-Qur'an. Dalam hal ini kepala sekolah memberikan pengarahan agar orang tua juga termotivasi agar tetap memberikan semangat kepada anak-anak mereka. Selain upaya yang dilakukan pihak sekolah dan pemberian motivasi oleh orang tua, diharapkan juga ada kebijakan atau bantuan dari pemerintah yang berkaitan dengan peningkatan minat belajara baca tulis al-Qur'an. Di Indonesia pemerintah telah ikut memberikan perhatian dalam keputusan bersama Menteri Dalam Negeri dan Menteri Agama RI N0. 128 tahun 198/44 A yang mengatakan perlunya usaha peningkatan kemampuan baca tulis al-Qur'an bagi ummat Islam dalam rangka peningkatan penghayatan dan pengamalan al-Qur'an dalam kehidupan sehari-hari.

\section{DAFTAR PUSTAKA}

Bahri Syaiful Djamarah. Psikologi Belajar. Jakarta. Rineka Cipta. 2002.

Kementerian Agama Republik Indonesia. Al-Qur'an dan terjemahnya. Semarang. Toha Putra, 2009.

Rosyidah Zulfa. Upaya Guru Pendidikan Agama Islam Dalam Meningkatkan Kemampuan baca tulis Al-Qur'an pada anak didik di SDN Sidorejo 01 Doko Blitar. Skripsi Sarjana. Fakultas Tarbiyah UIN Malang. 2008.

Sagala Syaiful. Konsep dan Makna Pembelajaran. Cet.8. Bandung. Alfabeta. 2010.

Syihab Quraish. Lentera Hati. Bandung. Mizan. 1996.

Syarifuddin Ahmad. Mendidik Anak Menulis, Membaca, Dan Mencintai AL-qur'an. Jakarta. Gema Insani, 2004.

Undang-Undang Republik Indonesia No. 20 Ta;hun 2003. Tentang Sistem Pendidikan Nasional 2003. Jakarta. Cemerlang. 2003.

Zarman Wendi. Ternyata Mendidik Anak Cara Rasulullah Itu Mudah \& Lebih Efektif. Cet. IV. Bandung. Ruang Kata Imprint Kawan Pustaka. 2012. 